\title{
EFFECT OF PARTICLE SIZE ON THE FROTH FLOATATION OF SOKOTO PHOSPHATE ORE
}

\author{
U.A. Hassan ${ }^{1}$, S.A. Yaro ${ }^{2}$, M. Abdulwahab ${ }^{3}$, M.R. Dodo ${ }^{3 *}$ \\ ${ }^{1}$ Federal ministry of solid minerals, Nigeria \\ ${ }^{2}$ Shell Professor, Department of Mechanical Engineering, Ahmadu Bello \\ University, Nigeria \\ ${ }^{3}$ Department of Metallurgical and Materials Engineering, Ahmadu Bello
}

Received 12.04.2016

Accepted 18.05.2016

\begin{abstract}
Effect of particle size on the froth floatation of Sokoto phosphate ore for its beneficiation has been investigated and established. The research has been conducted using various reagents, $\mathrm{pH}(\mathrm{s})$ at different sieve size fractions. Bench scale flotation tests were carried out on $-250+180 \mu \mathrm{m},-180+106 \mu \mathrm{m},-106+75 \mu \mathrm{m},-75+45 \mu \mathrm{m}$ and $-45+38 \mu \mathrm{m}$ particle size fractions after screening in order to determine the optimum flotation feed size distribution using 1 liter Denver flotation cell. The results of the scoping flotation studies using a conditioning Pulp Density of $60 \%$ Solids, $\mathrm{pH} 9,800 \mathrm{~g} / \mathrm{t}$ reagent dosage for AERO704 Promoter (Fatty Acid) and flotation pulp density of $28.5 \%$ Solids show that $+106 \mu \mathrm{m}$ particle size gave the highest assay content of $20.4 \% \mathrm{P}_{2} \mathrm{O}_{5}$ with a recovery of $76.2 \%$ compared to $+38 \mu \mathrm{m}\left(19.9 \% \mathrm{P}_{2} \mathrm{O}_{5}\right.$ and recovery of $\left.43.2 \%\right)$ and $+180 \mu \mathrm{m}$ $\left(19.4 \% \mathrm{P}_{2} \mathrm{O}_{5}\right.$ and $24.1 \%$ recovery) in their floats (concentrates) but with no perfect separation as the tailings fraction also contained similar grades with slight differences. Keywords: Sokoto phosphate rock, beneficiation, deposit, metallurgical grade, AERO 704 (fatty Acid), Flotation, particle size.
\end{abstract}

\section{Introduction}

Mineral Phosphates are complex minerals which are the basic forms of the primary sources of phosphorus, an element necessary to all forms of plants, animals and human life. Phosphorus finds many applications in life. With the urgent need for intensive farming due to increasing population, the fertility of the soil needs to be maintained by its external additions [1].

Nigeria has been importing fertilizers and other phosphorus related products for farming as well as to sustain her agricultural program. This has led to the importation of millions of metric tons of fertilizer amounting to millions of US (United States)-dollars

\footnotetext{
* Corresponding author: Mamuda Rayyan Dodo, rdmamuda@abu.edu.ng
} 
from the United States of America and other countries within the African continent like Tunisia, Senegal, Morocco and Togo despite the large deposits of phosphate mineral ores available in the country.

In the Florida is the source of about $73 \%$ of the phosphate rock produced, North Carolina accounts for $15 \%$ while Western phosphate and Tennessee accounts for $12 \%$ of the total production of phosphate mineral ores [2]. The matrix of the ores mineralogy is predominantly flouapatite orfrancolite (sometimes called collophane), in which an excess of fluorine and carbon replaces phosphate in the apatite lattice. They are marine sedimentary deposits and rocks and sometime oolitic in nature. Phosphate contents of the deposits are classified into two: low grade ranging between 14.6 to $29 \% \mathrm{P}_{2} \mathrm{O}_{5}$ and high grades from $30 \% \mathrm{P}_{2} \mathrm{O}_{5}$ and above. The lime-to-phosphate $\left(\mathrm{CaO} / \mathrm{P}_{2} \mathrm{O}_{5}\right)$ ratio of the deposits is within 1.59 to 2.1 in some cases, with low iron and alumina. Other minerals in association are silica, magnesium, chloride, lithium, feldspar and fluorite [3].

However, it is important to note that phosphate minerals are not found on the earth crust in a significant concentration that is required for optimum plant growth; this is the main reason why there is need to artificially add this mineral to the soil in the form of fertilizer. In view of the strategic importance of fertilizer to food security since no tangible farm produce can be produced without fertilizer and the fact that no known fertilizer grade is currently produced in the country, this makes the research worthy. Hence, there is need to beneficiate the Sokoto phosphate rock deposit to a metallurgical grade that can be used as feed for the production of fertilizer and other phosphorus based products.

\section{Materials and methods}

Samples

$50 \mathrm{~kg}$ of samples for test work were obtained by collecting random samples of Sokoto phosphate resource (rock and shale) mined by artisanal miners in Dange-Shuni, Bodinga, Yabo, Wurno, and Rabbah Local Government Area of Sokoto State. These were sorted to produce phosphate nodules that were blended and re-sampled to produce composite working quantities.

\section{Equipment/Apparatus}

Denver flotation cell, XRF, small size laboratory jaw crusher, cone crusher, pulverizing machine, standard sieve shakers (sieve size fractions: $-250+180 \mu \mathrm{m}$, $180+106 \mu \mathrm{m},-106+75 \mu \mathrm{m},-75+38 \mu \mathrm{m})$, Wifley shaking table.

\section{Reagents}

Reagents used in the research work comprised AERO 704 (Fatty Acid), sodium carbonate, Reagent S-9849, (an alcoholic solution of alkyl hydroxamic acid from Cytec), Aerofroth 70 (methylisobutylcarbinol - MIBC), Dextrin, Phosphoric Acid and Melamine.

Methodology

Composite sample of Sokoto phosphate rock was subjected to the laboratory separation tests. 


\section{Laboratory Separation test}

Bench Scale Flotation Tests

Bench Scale Flotation tests were carried out on $-250+180 \mu \mathrm{m},-180+106 \mu \mathrm{m}$, $106+75 \mu \mathrm{m},-75+45 \mu \mathrm{m}$ and $-45+38 \mu \mathrm{m}$ particle size fractions after screening in order to determine the optimum flotation feed size distribution using 1 liter Denver flotation cell.

The procedures for carrying out the test are as follows:

Predetermined volume of water was added into the one Liter flotation cell, depending on the conditioning pulp density $(55 \%, 60 \%$ and $65 \%$ adopted based on findings by Zhang [4]) to be used. 350g of ground phosphate rock was then added and conditioned for two minutes at desired percent solids (55\%,60\% and 65\%). Make up water was added and mixed for thirty seconds. Air was then introduced with floated material collected until froth contains clean air bubbles. Collected float materials were dried in an oven and analyzed for $\mathrm{P}_{2} \mathrm{O}_{5}$ using XRF Pan Analytical Mini PAL4 analyzer.

\section{RESULTS AND DISCUSSION}

Scoping Flotation Test Results

Table I gives the result of the Scoping flotation studies of the Sokoto phosphate mineral ore whereas Figures 1 and 2 show the \% Assay of $\mathrm{P}_{2} \mathrm{O}_{5}$ and \%Recovery of floated phosphate sample against sieve size fractions using a conditioning Pulp Density of $60 \%$ Solids, $\mathrm{pH} 9,800 \mathrm{~g} / \mathrm{t}$ Alkyl Hydroxamates dosage and flotation pulp density of $28.5 \%$ Solids.

Table I: Results of the Scoping Flotation Studies using a conditioning Pulp Density of $60 \%$ Solids, $\mathrm{pH} 9,800 \mathrm{~g} / \mathrm{t}$ reagent dosage and flotation pulp density of $28.5 \%$ Solids

\begin{tabular}{|c|c|c|c|c|c|c|c|c|c|}
\hline \multirow{3}{*}{$\begin{array}{l}\text { Fractions / } \\
\text { Parameter }\end{array}$} & \multicolumn{9}{|c|}{ Reagent S-9849 Promoter(Alkyl Hydroxamates) } \\
\hline & \multicolumn{3}{|c|}{$-106+38 \mu \mathrm{m}$} & \multicolumn{3}{|c|}{$-180+106 \mu \mathrm{m}$} & \multicolumn{3}{|c|}{$-250+180 \mu \mathrm{m}$} \\
\hline & Wt (g) & $\%$ & $\%$ & Wt (g) & $\%$ & $\%$ & Wt (g) & $\%$ & $\%$ \\
\hline & & $\mathbf{P}_{2} \mathbf{O}_{5}$ & Rec. & & $\mathbf{P}_{2} \mathbf{O}$ & Rec. & & $\mathbf{P}_{2} \mathbf{O}_{5}$ & Rec. \\
\hline Floats & 220.2 & 19.4 & 61.5 & 89.4 & 21.7 & 25.0 & 72.1 & 21.2 & 19.4 \\
\hline Tailings & 129.8 & 20.6 & 38.5 & 260.6 & 22.3 & 75.0 & 277.9 & 22.9 & 80.6 \\
\hline Feed & 350.0 & 19.8 & 100 & 350.0 & 22.1 & 100 & 350.0 & 22.5 & 100 \\
\hline \multicolumn{10}{|c|}{ Recovery $(\%)=[(\mathrm{Cc} / \mathrm{Ff}) * 100]$} \\
\hline
\end{tabular}

Figure 1 and 2 show that the scoping test did not produce a clean separation of the $\mathrm{P}_{2} \mathrm{O}_{5}$ mineral content from the associated minerals as shown by the minor differences $[19.4 \%$ for float against $20.6 \%$ for Tailings in case of $+38 \mu \mathrm{m}$ size range fraction; $21.7 \%$ for floats against $22.3 \%$ for tailings in the case of $+106 \mu \mathrm{m}$ size fraction; and $21.2 \%$ for float against $22.9 \%$ for tailings in the case of +180 fraction]. This is attributable to the collophane nature of the Sokoto phosphate rock which makes liberation of associated minerals at the flotation sizes impossible. The results also showed that $+38 \mu \mathrm{m}$ gave the highest recovery figure of $61.5 \%$ as against $25 \%$ and $19.4 \%$ recorded for $+106 \mu \mathrm{m}$ and +180 fractions respectively. The significant difference in the recovery figures is attributable to the difficulty associated in lifting mineral particles into the float fraction by air bubbles with increasing particle size [3]. 


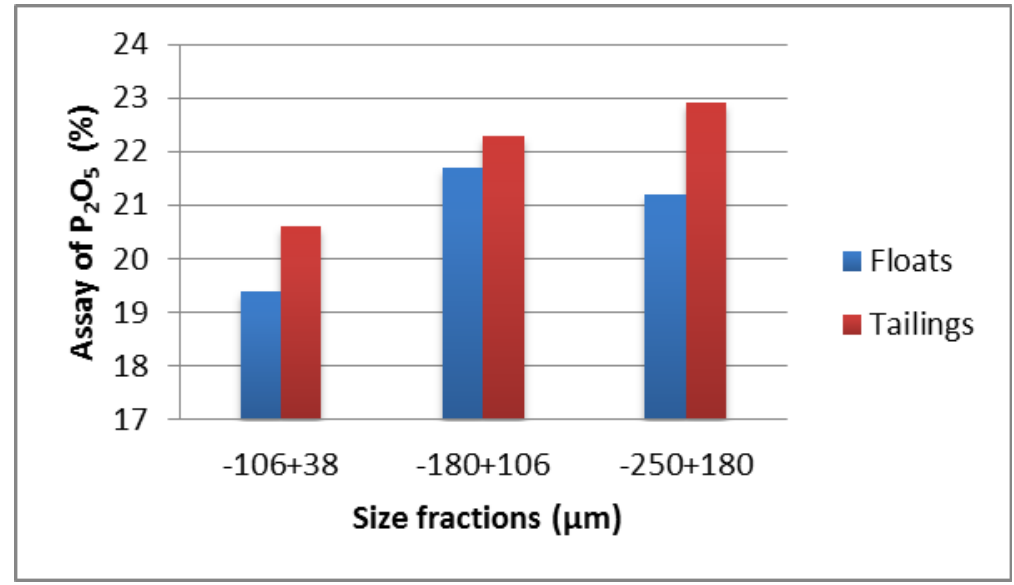

Fig.1. \% Assay of $\mathrm{P}_{2} \mathrm{O}_{5}$ of floated phosphate sample against sieve size fractions using reagent S-9849 promoter (Alkyl Hydroxamates), $800 \mathrm{~g} / \mathrm{t}$, flotation pulp density of $28.5 \%$ solids, at pH9, conditioning pulp density of $60 \%$ solids.

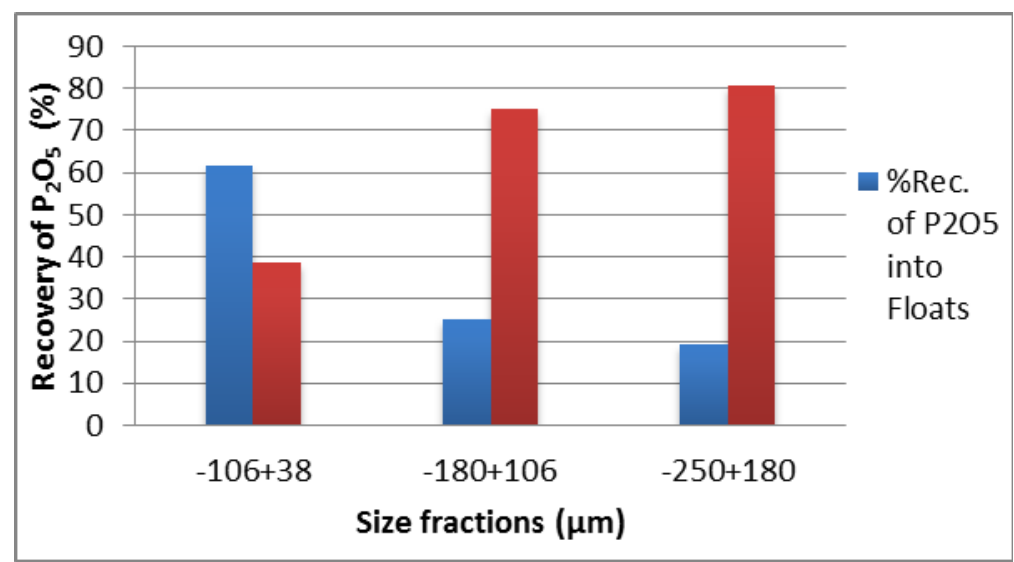

Fig. 2. \%Recovery of floated phosphate sample against sieve size fractions using reagent S-9849 promoter (Alkyl Hydroxamates), $800 \mathrm{~g} / \mathrm{t}$, flotation pulp density of 28.5\%solids, at pH9, conditioning pulp density of 60\%solids.

Table II and Figures 3 and 4 depict the results of the scoping flotation studies using a conditioning Pulp Density of $60 \%$ Solids, $\mathrm{pH} 9,800 \mathrm{~g} / \mathrm{t}$ reagent dosage for AERO704 Promoter (Fatty Acid) and flotation pulp density of $28.5 \%$ Solids. From the result, the $+106 \mu \mathrm{m}$ size gave the highest assay content of $20.4 \% \mathrm{P}_{2} \mathrm{O}_{5}$ with a recovery of $76.2 \%$ compared to $+38 \mu \mathrm{m}\left(19.9 \% \mathrm{P}_{2} \mathrm{O}_{5}\right.$ and recovery of $\left.43.2 \%\right)$ and $+180 \mu \mathrm{m}$ $\left(19.4 \% \mathrm{P}_{2} \mathrm{O}_{5}\right.$ and $24.1 \%$ recovery) in their floats (concentrates) but with no clean separation as the tailings fraction also contained similar grades with marginal differences. This is also attributable to non-liberation of associating minerals and the difficulty in lifting mineral particles into the float fraction with increasing particle size. 
Table II: Scoping Flotation Studies using a conditioning Pulp Density of 60\% Solids, pH9, 800g/t reagent dosage for AERO 704 Promoter (Fatty Acid) and flotation pulp density of $28.5 \%$ Solids.

\begin{tabular}{|c|c|c|c|c|c|c|c|c|c|}
\hline \multirow{4}{*}{$\begin{array}{l}\text { Fractions / } \\
\text { Parameter }\end{array}$} & \multicolumn{9}{|c|}{ AERO704 Promoter (Distilled Tall-oil Fatty Acids) } \\
\hline & \multicolumn{3}{|c|}{$-106+38 \mu m$} & \multicolumn{3}{|c|}{$-180+106 \mu \mathrm{m}$} & \multicolumn{3}{|c|}{$-250+180 \mu \mathrm{m}$} \\
\hline & Wt (g) & $\% \mathbf{P}_{2}$ & $5 \%$ & Wt (g) & $\%$ & $\%$ & Wt (g) & $\%$ & $\%$ \\
\hline & & & Rec & & $\mathbf{P}_{2} \mathbf{O}_{5}$ & Rec. & & $\mathbf{P}_{2} \mathbf{O}_{5}$ & Rec. \\
\hline Floats & 259.8 & 19.9 & 76.2 & 158.2 & 20.4 & 43.2 & 91.5 & 19.4 & 24.1 \\
\hline Tailings & 74.2 & 21.7 & 23.8 & 191.8 & 22.1 & 56.8 & 258.5 & 21.7 & 75.9 \\
\hline Feed & 350.0 & 19.4 & 100 & 350.0 & 21.3 & 100 & 350.0 & 21.1 & 100 \\
\hline$(\%)$ Rec. $=$ & $\mathrm{c} / \mathrm{Ff})^{* 1}$ & & & & & & & & \\
\hline
\end{tabular}

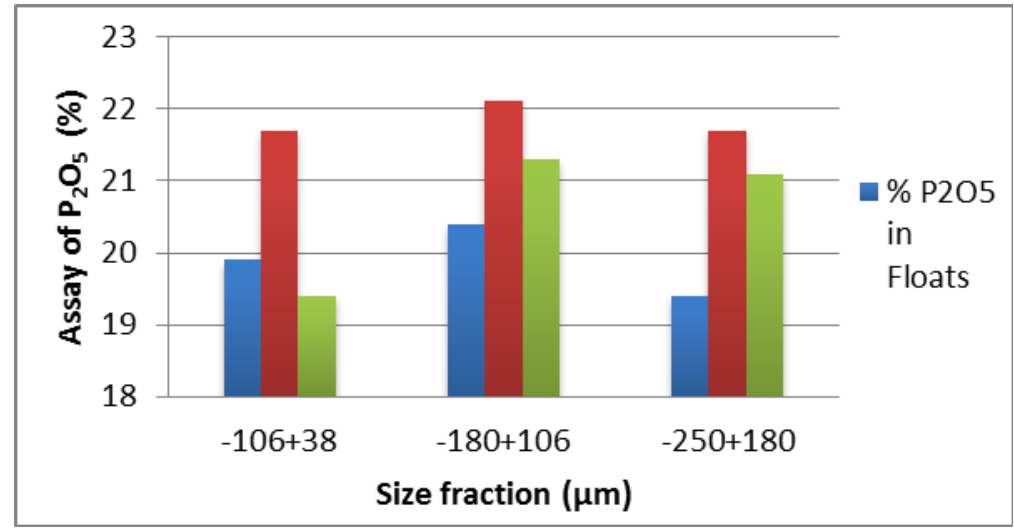

Fig. 3. \% Assay of $\mathrm{P}_{2} \mathrm{O}_{5}$ of the Flotation Fractions using AERO704 Promoter.

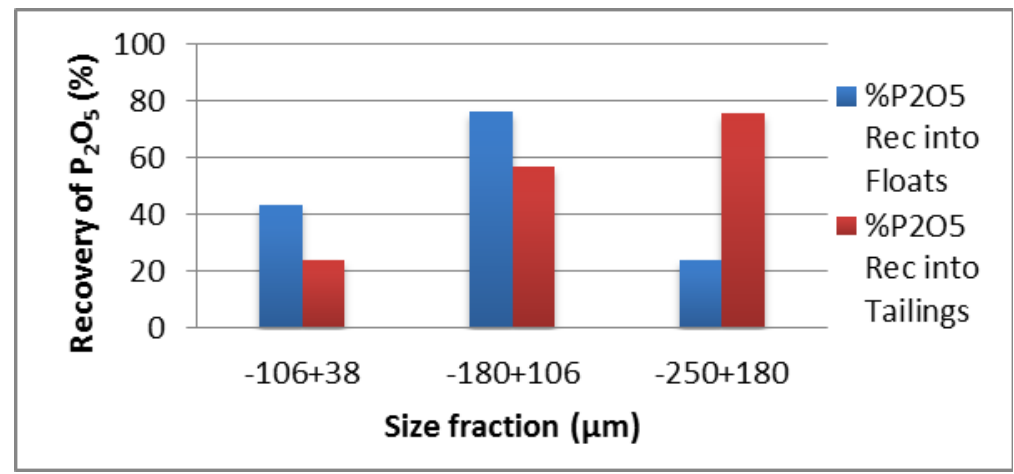

Fig. 4. \% Recovery of $\mathrm{P}_{2} \mathrm{O}_{5}$ into flotation Fractions using AERO704 Promoter. 
Figure 5 shows the recovery figures for $\mathrm{P}_{2} \mathrm{O}_{5}$ components floated into the float fractions using AERO704 and Alkyl Hydroxamates. The higher recovery figures recorded for $\mathrm{P}_{2} \mathrm{O}_{5}$ component recovered into the floated fractions when the various sized fractions were floated using AERO704 Promoter were $76.2 \%, 43.2 \%$ and $24.1 \%$ for the respective size fractions of $+38 \mu \mathrm{m},+106 \mu \mathrm{m}$ and +180 . In contrast to the figures obtained when floated with reagent S-9849 Promoter(Alkyl Hydroxamates), the recovery figures generated for the $\mathrm{P}_{2} \mathrm{O}_{5}$ for $+38 \mu \mathrm{m},+106 \mu \mathrm{m}$ and $+180 \mu \mathrm{m}$ size fractions were $61.5 \%, 25.0 \%$ and $19.4 \%$ respectively. It is clear from this; AERO704 is a better collector for the Sokoto Phosphate rock than reagent S-9849 Promoter (Alkyl Hydroxamates).

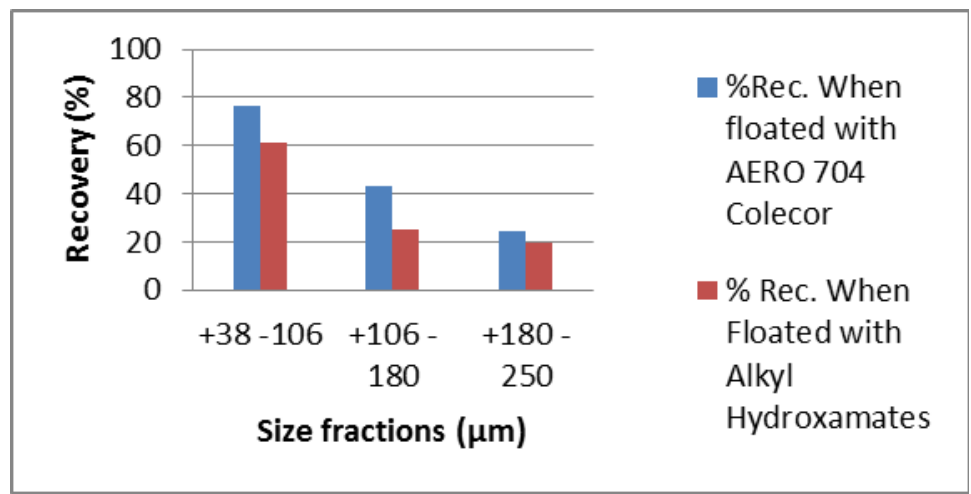

Fig. 5. Recovery figures for $\mathrm{P}_{2} \mathrm{O}_{5}$ Components recovered into Float Fractions collected using AERO704 and Alkyl Hydroxames as collectors at pH9.

\section{Calcite flotation Test}

Table III and Figures 6 and 7 give the result of calcite flotation of Sokoto phosphate rock at $\mathrm{pH} 9$ using Melamine as collector, Dextrin as depressant for phosphate rock and MBIC as frother. In Table III the result shows that the flotation test on the $75+45 \mu \mathrm{m}$ size fraction produced a concentrate (float) product weighing $31.1 \%$ of the feed, assaying $23.3 \% \mathrm{P}_{2} \mathrm{O}_{5}$ with a recovery of $30.4 \%$ of the $\mathrm{P}_{2} \mathrm{O}_{5}$ content. The test on the $-106+75 \mu \mathrm{m}$ sieves size fraction produced a float product weighing $13.4 \%$ of the feed assaying $25.4 \% \mathrm{P}_{2} \mathrm{O}_{5}$ with a recovery of $13.0 \%$ of the $\mathrm{P}_{2} \mathrm{O}_{5}$ content while the test on the $45+38 \mu \mathrm{m}$ fraction produced a float product assaying $22.1 \% \mathrm{P}_{2} \mathrm{O}_{5}$ containing $4.7 \%$ of the $\mathrm{P}_{2} \mathrm{O}_{5}$ contained in the feed. Figures 6 and 7 showed the behavioral trends of the \% assays and recoveries of $\mathrm{P}_{2} \mathrm{O}_{5}$ into floats and the tailings recovered during the scoping flotation tests of calcite flotation. The results reveal low froth collection as shown by the various weight percentages for all the size fractions tested as well as no clean separation of the valuable $\mathrm{P}_{2} \mathrm{O}_{5}$ content as revealed by the grades of the floats and tailings products produced.

The lack of clean separation can be explained by inadequate liberation of the $\mathrm{P}_{2} \mathrm{O}_{5}$ valuable content arising from the collophane nature of the test material which made liberation at the test sizes impossible [3]. 
Table III: Calcite Flotation at pH9 using Melamine as collector, Dextrin as depressant for phosphate rock and MBIC as frother.

\begin{tabular}{|c|c|c|c|c|c|c|c|c|c|}
\hline \multirow{2}{*}{$\begin{array}{l}\text { Fraction / } \\
\text { Parameter }\end{array}$} & \multicolumn{3}{|c|}{$-106+75 \quad(\mu \mathrm{m}) \%$} & \multicolumn{2}{|c|}{$-75+45(\mu \mathrm{m})$} & \multirow{2}{*}{$\begin{array}{l}\% \\
\text { Rec. }\end{array}$} & \multicolumn{2}{|c|}{$-45+38(\mu \mathrm{m})$} & \multirow{2}{*}{$\begin{array}{l}\% \% \\
\text { Rec. }\end{array}$} \\
\hline & Wt (g) & $\% \mathrm{P}_{2}$ & Rec. & $\overline{\text { Wt (g) }}$ & $\%$ & & $\overline{\text { Wt (g) }}$ & $\%$ & \\
\hline Float & 46.8 & 25.4 & 13.0 & & $\begin{array}{l}\mathbf{P}_{\mathbf{2}} \mathbf{O}_{5} \\
23.3\end{array}$ & 30.4 & 17.5 & $\begin{array}{l}\mathbf{P}_{\mathbf{2}} \mathbf{O}_{5} \\
22.1\end{array}$ & 4.7 \\
\hline Tailings & 303.2 & 26.2 & 87.0 & 241.2 & 24.0 & 69.6 & 332.5 & 23.3 & 95.3 \\
\hline Feed & 350.0 & 26.1 & 100 & 350.0 & 23.8 & 100 & 350.0 & 23.2 & 100 \\
\hline
\end{tabular}

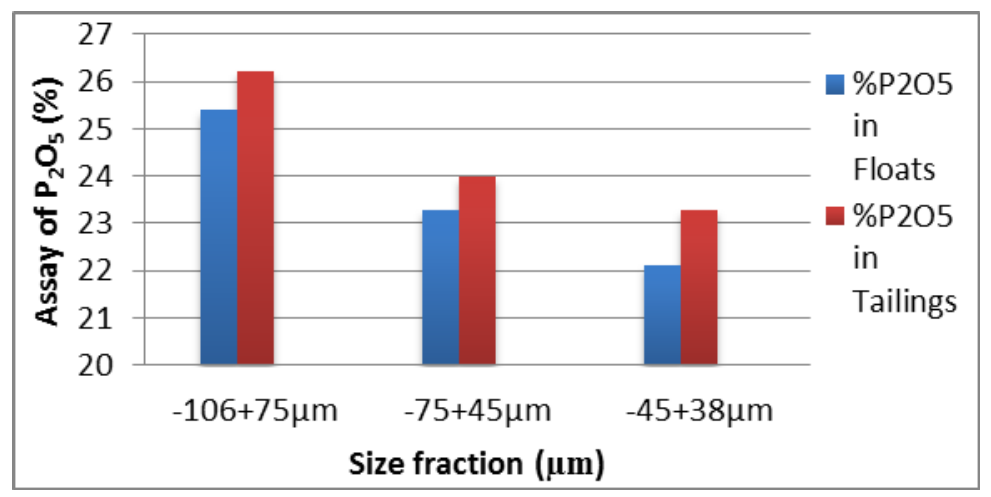

Fig. 6. \% Assay of $\mathrm{P}_{2} \mathrm{O}_{5}$ in floats recovered during Scoping Flotation Tests of Calcite Flotation at pH9 using Melamine as collector, Dextrin as depressant for phosphate rock and MBIC as frother.

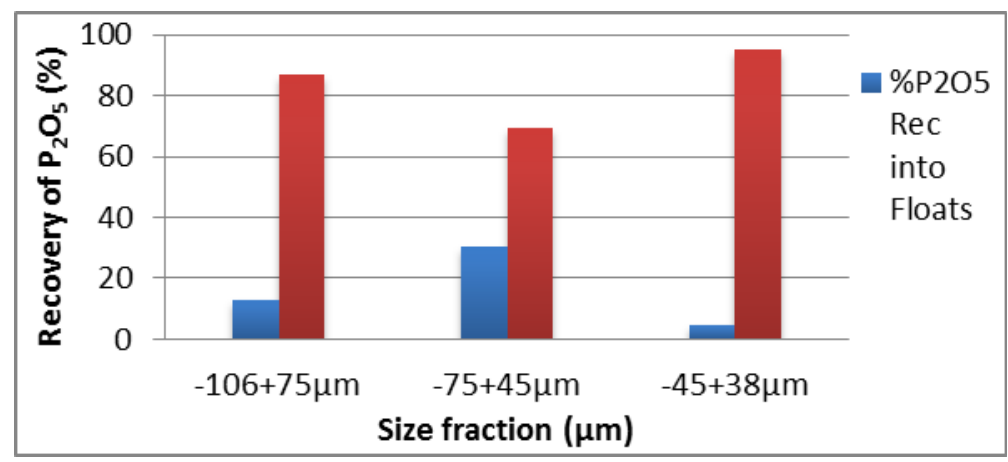

Fig. 7. Recoveries of $\mathrm{P}_{2} \mathrm{O}_{5}$ in floats recovered during Scoping Flotation Tests of Calcite Flotation at pH9 using Melamine as collector, Dextrin as depressant for phosphate rock and MBIC as frother.

\section{Conclusions}

At the end, it can be concluded that:

$>$ The separation of the chemical compound of the Sokoto phosphate mineral ore into float and tailings shows that the Sokoto phosphate ore could respond 
to froth flotation condition processes and hence could be beneficiated using froth flotation mineral processing technique.

$>$ Scoping flotation process using AERO704 Promoter (Fatty Acid) depict that $+106 \mu \mathrm{m}$ particle size gave the highest assay content and recovery compared to $+38 \mu \mathrm{m}$ and $+180 \mu \mathrm{m}$.

$>$ The results of the calcite flotation process revealed low froth collection as shown by the various weight percentages for all the size fractions tested as well as no clean separation of the valuable $\mathrm{P}_{2} \mathrm{O}_{5}$ content.

$>$ AERO704 is a better collector for the Sokoto Phosphate rock than reagent S9849 Promoter (Alkyl Hydroxamates).

\section{References}

[1] Encyclopedia Britanica.www.britanica.com/EBchecked/topic/457399/phosphatemineral, Accessed 28/6/2010

[2] Fuerstenau C. M. and Han N. K. (2003).Principles of Mineral Processing, Society for Mining, Metallurgy, and Exploration, U. S. A., PP245 - 306

[3] Weiss, N.L., (1985). Mineral Processing Handbook, American Institute of Mining Metallurgical and Petroleum Engineering Incorporated in the United States of America, Kings Port Press, PP5/72 - 5/79; 21/1 - 21/17

[4] Zhang P. An Investigation of Flotation Reagents, FIPR 97-02-125, www.fipr.state.fl.us/FIPRreport2003/recently-completed-contractsbeneficiation.htm(Accessed 6/28/2010)

[5] Carr D. D. Industrial Minerals and Rocks, Society of Mining, Metallurgy and Exploration Inc, Pp751 - 764. 1994.

[6] Gruber G., Pilot Plant Demonstration of Anionic Rougher - Cleaner Flotation on Florida Phosphate, Final Report 02-151-200, FIPR 01-02-151, www.fipr.state.fl.us/FIPRreport2003/recently-completed-contractsbeneficiation.htm (Accessed 28/6/2010). 2003.

[7] GSD. Geological Survey Report on Sokoto Phosphate Deposit, Dange- Shuni LGA, unpublished. 1991.

[8] Gupta and Yan. Mineral Processing Design and Operations, PP555 - 621. 2006.

[9] Jones, M. P. Applied Mineralogy, A quantitative Approach, pp 13 - 69, 150 -176. 1987.

[10] Miller J. D. A Selective Collector for Phosphate Flotation, Final Report 02-142187, FIPR 00-02-142, 2003. www.fipr.state.fl.us/FIPRreport2003/recentlycompleted-contracts-beneficiation.htm , Accessed - 28/6/2010

[11] Mular, L., \& Bhappu, R. B., SME Mineral Processing Plant Design, $2^{\text {nd }}$ Edition, Pp113 - 306, 447 - 465. 1980.

[12] Nigerian Mining Corporation. Feasibility Study Report on Sokoto Phosphate Deposit, Dange-Shuni LGA, unpublished. 1991.

[13] Thomas, D.G., and Adewuyi, E.A. Effects of Local Frothers on the Flotation of Toto MuroIron Ore By. Proceedings of the $35^{\text {th }}$ Confer of the Nigerian Society of Chemical Engineers, Pp116-120. 2005.

[14] Thompson P. The Selection of Flotation Reagents via Batch Flotation Test. In: SME Mineral Processing Plant Design, Practice, and Control: Proceedings, Vols. 1, Pp137 - 144. 2002.

[15] Umar, A.H, Characterization and design process flowsheet for the Beneficiation of Sokoto phosphate, Ph.D Thesis, A.B.U., Zaria. 2014. 